\title{
Economic Forces and the Stock Market Performance in Developing Countries: Evidence From Sudan
}

\author{
Nawal Hussein Abbas Elhussein ${ }^{1} \&$ Elzibeer Fath Elrahman Hamed Warag ${ }^{2}$ \\ ${ }^{1}$ School of Management Studies, University of Khartoum, Khartoum, Sudan \\ 2 Bassar Engineering company, Khartoum, Sudan \\ Correspondence: Nawal Hussein Abbas Elhussein, Mississauga, Ontario, L5B 3Z1, Canada. Tel: 1-289-724-2722.
}

Received: February 29, 2020

Accepted: March 30, 2020

Online Published: June 28, 2020

doi:10.5430/ijfr.v11n4p130

URL: https://doi.org/10.5430/ijfr.v11n4p130

\begin{abstract}
This paper is an attempt to empirically investigate the determinants of the stock market performance in Sudan. It aims at identifying the short and long run relationships between the Khartoum Stock Exchange all- share price index (KSI) as an indicator of market performance and some selected micro and macro-economic factors. The inflation rate, cost of capital, foreign exchange rate, broad money supply, and crude oil price are chosen as proxies for macroeconomic factors. The market oriented indicators used include market capitalization, market trading system, and market trading volume. The study covers the period 2003-2017. The paper employs the Multivariate Time Series Regression Analysis to estimate the short run relationship between the selected independent variables and the KSE price index. Soren Johansen's Cointegration Test and Vector Error Correction Model (VECM) have been employed to identify the long run equilibrium relationship among the variables. To estimate the causal relationship between the selected variables Toda-Yamamoto (T-Y) Granger Causality Test has been utilized. The study documents that the Khartoum Stock Exchange performance is significantly affected both by micro and macroeconomic factors. In the long run, all the independent variables with the exception of the cost of capital, have a significant positive relationship with KSI. However, in the short run the determinants of the stock market performance are market capitalization, market trading volume, money Supply, and cost of capital.
\end{abstract}

Keywords: stock markets, market capitalization, market trading system, market trading volume, macroeconomic indicators

\section{Introduction}

For more than three decades stock markets have boomed in just about every developing country. This stems from the recognition that the establishment of stock markets is essential for the generation of capital needed for economic development and growth. A developed stock market, as concluded by many articles on stock markets, is as important to national economic growth as banks. Though each provides a different set of important services, they both stimulate the accumulation of capital and contribute to improvements in productivity. Capital markets aid growth by channeling savings into investments. By providing long-term debt and equity finance for the government and corporate sector and by allowing individuals, risk averse investors in particular, to invest in a large number of firms and diversify their portfolios, capital markets add to a country's stock of capital goods which leads in turn to increases in output and finally raises the standard of living of the country. Furthermore, capital markets can raise the portion of financial resources available for investment by increasing liquidity, helping enterprises to raise funds that would otherwise, and at best, be put in less productive uses, providing an alternative as well as a complementary source of discipline, which is expected to enhance the economic efficiency of the listed firms and attracting foreign savings, which provide an important supplement in supplying productive investments. The concern about establishing an organized stock exchange in Sudan dates back to the early nineteen sixties. The extensive discussions, debates, and studies on the subject resulted in 1974 in a secretarial office for the stock exchange market set up within the Central Bank of Sudan. Astonishingly, it took the office seven years to prepare the Stock Exchange Act of 1982. Since then the stock exchange was established as a department in the Bank of Sudan and was expected to function under the control of the Ministry of Finance and Economic Planning. Again many years elapsed before the sincere efforts for establishing an organized stock exchange in Sudan turned to be a reality. The Khartoum Stock Exchange (KSE) Act 1994, abolishing that of 1982, was passed in 1994, and finally, after a search for a stock exchange that 
goes back over thirty years, Sudan has its first ever stock exchange, which has been in operation for more than 26 years by the end of 2019 .

The contribution of capital markets to economic development and growth depends on their operational and informational efficiency which is largely affected by several internal as well as external factors. The performance of stock markets is dependent on the association between stock price movements and the micro and macroeconomic variables that characterize the environments in which they operate. A conducive macroeconomic environment promotes the growth of businesses and elevates their achievements and hence is expected to positively impact the functioning of stock markets. The relationship between the performance of stock markets and the macroeconomic variables like the gross domestic product, interest rate, inflation rate, money supply, exchange rate, and index of industrial production has been extensively researched in developed and emerging markets. However, in developing countries there is a lack of research in this area. The empirical literature has confirmed that the stock market return is affected by the macroeconomic factors, though in varying degrees.

This paper is an attempt to explain how changes in stock prices are associated with macroeconomic indicators and market related factors, as well as their causal relationship for a developing capital market; Khartoum Stock Exchange (KSE). The rest of the paper is organized as follows: Section two provides a review of the literature concerning the relationship between macroeconomic indicators and the stock market performance. Section three describes the methodology followed and the methods of analysis employed. Section four presents the empirical results and their discussion. Section five provides a summary and concluding remark.

\section{Literature Review}

The Macroeconomic variables do have considerable influence, positive as well as negative, on the performance of the corporate sector of the economy. Consequently, stock markets got affected by their performance. The movement of stock prices, apart from the firms' fundamentals, is determined by the level of development of their economies. The two major theories on security pricing; the Capital Asset Pricing Model (CAPM) and the Arbitrage Pricing Theory (APT) suggest that non-diversifiable market risk and micro and macroeconomic factors influence expected security returns and prices. Following the pioneering work of Chen et al (1986) who conclude that stock returns and prices do depend on their exposure to variables that describe the economy, significant empirical research on the impact of macroeconomic variables on the performance of stock markets has been carried out. For instance, Kaul (1987), Barro (1990), Schwert (1990), Balvers et al., (1990), Chen (1991), Lee (1992), Abdullah and Hayworth (1993), Cheng (1995) and Mukherjee and Naka (1995) show that stock returns are strongly related to measures of domestic economic activity such as inflation, interest rates, discount rate, money supply and industrial production growth. These researches employ a number of statistical methods, including the Vector Autoregressive (VAR) model, Vector Error Correction (VEC) model, Cointegration test, Canonical Correlation analysis, Regression analysis and Granger causality test. More recent studies, which have been carried out in emerging markets and developing countries, incorporate oil prices, GDP, exchange rate and cost of capital as influential measures. The domain covered by these studies vary; some research a group of markets, others two markets and a third category only one market. For instance, Wongbangpo and Sharma (2002), investigate the role of selected macroeconomic variables, including the exchange rate, GNP, the consumer price index, the money supply and the interest on the stock prices in five emerging Asian countries; Indonesia, Malaysia, Philippines, Singapore, and Thailand. The study documents long and short term relationships between stock prices and these macroeconomic variables. Moreover, the macroeconomic variables in these countries cause and are caused by stock prices. Abugri (2008), studies whether key macroeconomic indicators, namely, the exchange rate, interest rate, industrial production, and money supply in four Latin American emerging markets; Argentina, Brazil, Chile, and Mexico, affect market returns. His study indicates that the country macroeconomic variables are consistently significant in explaining the returns in all the markets under the study. Megaravalli and Sampagnaro (2018), examine the impact of the exchange rate and inflation on the stock markets of India, China, and Japan. Their results demonstrate that the exchange rate has a positive and significant relationship with the stock market in the short as well as the long run for all the three countries, whereas the inflation and stock market relationship is insignificant. In light of the recent sharp and continuous fluctuations in the crude oil price, Bagchi (2017), examines the relationship between crude oil prices volatility and stock markets in four emerging economies; Brazil, Russia, India, and China. He concludes that the stock price volatility is partly explained by volatility in crude oil price. As well Hosseini et al (2011) investigate the relationship between stock market indices and four macroeconomic factors; the crude oil prices, money supply, industrial production and inflation rate in the emerging markets of China and India. Their study indicates that there are both long and short run linkages between the macroeconomic variables and the stock market index in each of the two countries. The impact of macroeconomic variables on the emerging stock markets of India and Indonesia has been researched by Khandelwal (2018). His 
study reveals a long run relationship between the stock market index and the exchange rate, interest rate, money supply, and inflation for both countries, though the extent and direction of this relationship differ. Studies that concentrate on only one emerging market include Gunasekarage and Pisedtatalasai (2004), who examine the market in Sri Lanka, Büyüksalvarci and Abdioglu, (2010) who research the stock market in Turkey, Pal and Mittal (2011), Tripathi, and Seth (2014), Nath, Bandopadhyay, and Mondal (2014) and Mayur (2017) who research the Indian market, Czapkiewicz, and Stachowicz, (2016), who investigate the association between the stock market and main macroeconomic variables in Poland and Utomo, Wulandari, Shandy, Narmaditya, Handayati and Ishak (2019), who test the relationship between macroeconomic variables and Stock Exchange market in Indonesia. The study on the Turkish market documents that there is a causal relationship between the stock prices and the foreign exchange rate, gold price, money supply, index of industrial production and rate of inflation. The results further suggest that there is unidirectional long-run causality from stock price to macro variables, which implies that the stock market can be used as a leading indicator for future growth in the economy. Studies on the Indian market conclude that the exchange rate, Inflation, Interest rate, oil price and index of industrial production have a significant correlation with the stock market indicator. For Sri Lanka, the influential factors are inflation, interest rate and money supply. Similarly, the market in Indonesia is affected by inflation, and interest rate in addition to the exchange rate. The performance of the market in Poland is affected by the exchange rate, export volume, and rate of inflation.

There seems to be a dearth of research in this area in developing countries, especially those in Africa. Only a handful of studies have been published. Those studies select exchange rate, Inflation, Interest rate, money supply, GDP and oil price as yardsticks. The results of the studies carried out by Anthony Kyereboah-Coleman and Agyire-Tettey (2008) and Haruna, Yazidu and Paul (2013) show that Ghana stock exchange is significantly affected by the interest rate, inflation and exchange rate. Haruna et al (2013) add money supply as an influential factor. Aigbovo and Izekor (2015) and Amassoma and Bolarinwa (2018) investigate the impact of macroeconomic variables on stock market Index in Nigeria. They both conclude that there exists a long run relationship between the exchange rate, inflation and money supply and the stock market index. According to Aigbovo and Izekor (2015), additional factors, namely, industrial production index and international oil price do influence the stock market index either in the short-run or the long-run. Amassoma and Bolarinwa (2018) report GDP also as a factor impacting the stock market performance. The stock market in Kenya, as asserted by Kirui, Wawire and Onono (2014), is significantly affected by the exchange rate, whereas the impact of GDP, Inflation and interest rate is insignificant. Barakat, Elgazzar and Hanafy (2016) shed light on the relationship between the stock market and macroeconomic factors in Egypt and Tunisia. Their results indicate that there is a causal relationship in both markets between market index and exchange rate, money supply, and interest rate. However, the Egyptian market is also affected by inflation, whereas in Tunisia there is no causal relationship between inflation and the market index.

To conclude, in the absence of definite and agreed upon guidelines for incorporating macroeconomic variables when building stock pricing models, different researchers have included different factors in constructing their models. Further, the evidence drawn from these studies differ based on the type of the economy in which the market operates; developed economy, an emerging economy or a developing economy.

Though the empirical studies on the impact of the institutional settings on the performance of equity markets is somewhat limited the available literature argues that institutional settings is of great importance to their proper functioning. These include improved trading, sound accounting and information reporting systems, strong and readily enforceable legal procedures and effective clearing and settlement arrangements, (Abbas 2010). Further a strong positive association between development in information technology and stock market growth has been reported by Olweny (2015). Gani, A., Ngassam, C. (2008) examines the links between institutional factors and stock market development in a sample of eight Asian countries with developing as well as mature stock markets. Their results provide strong evidence that diffusion of technology is positively related to stock market expansion.

\section{Material and Methods}

The basic objective of this paper is to identify the long run relationship between the KSE all-share price Index (KSI) and a group of selected macroeconomic variables. Further, the study includes additional micro factors in its model to incorporate the impact of some internal factors on the performance of the market. The paper depends mainly on secondary data which is obtained from the monthly review publications issued by Khartoum Stock Exchange KSE Research and Publication Division, KSE Official Website, Central Bank of Sudan reports, and publications and Central Bureau of Statistics reports. The research uses quarterly data to conduct its analysis. Since macroeconomic variables are highly interdependent, using all of them as explanatory variables in affecting the stock market may pose a severe multi-collinearity problem to the extent that it may become difficult to delineate the separate effect of 
different variables on the stock market price movements. Thus the paper has selected a group of macroeconomic indicators, namely, Foreign Exchange Rate, Cost of Capital, Inflation Rate, International Crude Oil price, and Broad Money Supply as independent variables. In addition Market Capitalization, Market Trading Volume, and Market Trading System are chosen as proxies for the micro variables. An important point to note here is that since the financial system in Sudan is an Islamic system the average Murabahah rates have been used as a proxy of the cost of capital. The econometric model is expressed as follows:

$$
\mathrm{KSI}=\beta 0+\beta 1 \mathrm{MCAP}+\beta 2 \mathrm{MTV}+\beta 3 \mathrm{MTSY}+\beta 4 \mathrm{FEX} \mathrm{R}+\beta 5 \mathrm{CCPT}+\beta 6 \mathrm{INFR}+\beta 7 \mathrm{COIL}+\beta 8 \mathrm{MS}+\varepsilon \mathrm{t}
$$

Where:

KSI $=$ Khartoum Stock Index

MCAP = Market Capitalization

MTV = Market Trading Volume

MTSY = Market Trading System

FEXR = Foreign Exchange Rate

CCPT $=$ Cost of Capital

IFR = Inflation Rate

COIL =International Crude OIL Price

MS = Broad Money Supply

$\varepsilon \mathrm{t}=$ Error term.

Table 1 below provides a summary of the hypothetical relationship between the KSI and the independent variables.

Table 1. The hypothetical relationship between KSI and the independent variables

\begin{tabular}{lll}
\hline Hyp. No & Independent Variables & Hypothetical Relationship with KSI \\
\hline 1 & MCAP & Positive \\
\hline 2 & MTV & Positive \\
\hline 3 & MTS & Positive \\
\hline 5 & FEXR & Positive \\
\hline 6 & MS & Positive \\
\hline 7 & COIL & Positive \\
\hline 8 & INFR & Negative \\
\hline
\end{tabular}

Different types of statistical and econometric methods and tools have been employed to design a stock pricing methodology in this study. Multivariate Time Series Regression Analysis has been used to estimate the short run discrete relationship between the selected independent variables and the KSE price index. Soren Johansen's Cointegration Test and Vector Error Correction Model (VECM) have been employed to identify the long run equilibrium relationship among the variables. Finally, the Toda-Yamamoto (T-Y) Granger Causality Test has been utilized to identify VAR based causal relationships among the selected variables. Since it is $t$ is important for any time series data to be stationary, all the variables are tested for their stationarity through using Augmented-Dickey Fuller (ADF) Test and Phillips- Parron (PP) Test. The multivariate time series regression model is then developed according to the best suited specification between the dependent and independent variables. The presence of serial correlation in each of the regression models has been tested by employing the Breusch Godfrey Serial Correlation LM Test. The Histogram Normality Test (Jarque-Bera) has been utilized to test the residual normality distribution. To test the statistical significance of the regression coefficients in each of the regression models, the study uses the WALD Test. The White's General Heteroskedasticity (WGH) Test has been utilized to test the assumption of homoskedasticity in the regression model. Lastly, Ramsey's RESET test has been used to identify whether there is any specification error in the multivariate time series regression models. 


\section{Results}

Descriptive statistics and correlation matrix are employed by the study to provide insight into the characteristics of the data in order to enable the best selection of the model. The descriptive statistics of all the variables are presented in Table 2.

Table 2. Descriptive statistics of variables

\begin{tabular}{llllllllll}
\hline & KSI & MTV & MCAP & MS & MTSY & INFR & FEXR & COIL & CCPT \\
\hline Mean & 2525.87 & 666.17 & 8257.7 & 36348.7 & 0.4 & 17.7 & 4.3 & 75.0 & 11.3 \\
\hline Median & 2706.11 & 498.50 & 8563.4 & 27325.9 & 0.0 & 15.0 & 2.6 & 71.9 & 11.2 \\
\hline Maximum & 3259.17 & 1861.58 & 11412.7 & 93642.6 & 1.0 & 48.0 & 11.3 & 131.5 & 17.0 \\
\hline Minimum & 941.04 & 105.67 & 3312.8 & 6672.2 & 0.0 & 2.0 & 2.1 & 26.9 & 9.4 \\
\hline Std. Dev. & 602.26 & 437.96 & 1983.1 & 25550.9 & 0.5 & 12.2 & 2.8 & 27.0 & 1.4 \\
\hline Skewness & -1.52 & 1.19 & -1.1 & 0.8 & 0.4 & 1.1 & 1.1 & 0.0 & 2.6 \\
\hline Kurtosis & 4.7 & 3.56 & 4.1 & 2.5 & 1.2 & 3.1 & 2.7 & 1.9 & 12.2 \\
\hline Jarque-Bera & 76.58 & 12.53 & 13.7 & 6.2 & 8.4 & 9.8 & 10.0 & 2.6 & 233.1 \\
\hline Probability & 0.0000 & 0.002 & 0.001 & 0.044 & 0.015 & 0.008 & 0.007 & 0.074 & 0.000 \\
\hline
\end{tabular}

To identify the relative degree of association between the dependent and independent variables before using them in the regression model, the correlation coefficients have been calculated and tested for their statistical significance. As shown in Table 3 the estimates of the correlation coefficient and $p$-values for their $t$-statistics provide relative assurance that the independent variables which have been incorporated to estimate their explanatory power in explaining the change in the dependent variable have a strong statistical association.

Table 3. Correlation coefficients between stock price and selected variables

\begin{tabular}{llll}
\hline Variables & Correlation & t-Statistic & Prob \\
\hline KSI & 1 & & \\
\hline INFR & 0.283398 & 2.047374 & 0.0461 \\
\hline EXR & 0.291749 & 2.113234 & 0.0398 \\
\hline CCPT & -0.321617 & -2.35326 & 0.0228 \\
\hline MS & 0.392063 & 2.952689 & 0.0049 \\
\hline COIL & 0.408054 & 3.096614 & 0.0033 \\
\hline MCAP & 0.859091 & 11.62894 & 0.0000 \\
\hline MTSY & 0.242344 & 1.730599 & 0.0899 \\
\hline MTV & 0.395854 & 2.986515 & 0.0044 \\
\hline
\end{tabular}

The ADF and P-P unit root test has been employed to examine the stationarity of the stock price and the selected independent variables. The test results, which are displayed in Table 4 reveal that all variables with the exception of MTSY are integrated of order I(1) process. As such all the remaining endogenous variables are non-stationary, which necessitate the transformation of variables into their first differenced value to make them stationary

Table 4. Test of stationarity between stock price and independent variables

\begin{tabular}{|c|c|c|c|c|c|c|c|c|}
\hline & \multicolumn{4}{|c|}{ Augmented Dickey Fuller (ADF) Test } & \multicolumn{4}{|c|}{ Phillips-Parron (PP)Test } \\
\hline & $\mathrm{I}(0)$ & & $\mathrm{I}(1)$ & & $\mathrm{I}(0)$ & & $\mathrm{I}(1)$ & \\
\hline Variables & t-stat & Prob. & t-stat & Prob. & t-stat & Prob. & t-stat & Prob. \\
\hline KSI & 23.083 & 0.51 & 124.882 & 0.00 & 29.532 & 0.20 & 124.201 & 0.00 \\
\hline EX_RATE & 15.676 & 0.90 & 63.0931 & 0.00 & 15.120 & 0.92 & 63.3957 & 0.00 \\
\hline ССРТ & 10.322 & 0.99 & 856799 & 0.00 & 10.258 & 0.99 & 86.642 & 0.00 \\
\hline
\end{tabular}




\begin{tabular}{lllllllll}
\hline MS & 21.692 & 0.60 & 47.8562 & 0.00 & 21.851 & 0.59 & 47.8693 & 0.00 \\
\hline INF & 18.583 & 0.77 & 68.408 & 0.00 & 17.501 & 0.83 & 65.041 & 0.00 \\
\hline KSI & 23.083 & 0.51 & 124.882 & 0.00 & 29.532 & 0.20 & 124.201 & 0.00 \\
\hline MCAP & 22.390 & 0.56 & 138.959 & 0.00 & 27.349 & 0.29 & 138.356 & 0.00 \\
\hline MTV & 22.735 & 0.54 & 65.5601 & 0.00 & 27.615 & 0.28 & 65.0836 & 0.00 \\
\hline MTSY & & 0.00 & & & & 0.00 & & \\
\hline
\end{tabular}

The multivariate time series regression model between the stock price and the selected variables has been designed according to the following specification:

DLOG $(\mathrm{KSI})=\alpha+\beta 1 \mathrm{DLOG}(\mathrm{MCAP})+\beta 2 \mathrm{DLOG}(\mathrm{MTV})+\beta 3 \mathrm{DUMMY}$ MTSY $+\beta 4 \mathrm{DLOG}(\mathrm{MS})+\beta 5$ DLOG (INFR)

$$
+\beta 6 \text { DLOG }(\text { EXR })+\beta 7 \text { DLOG (COIL) }+\beta 8 \text { DLOG }(\text { CCPT })+\mathrm{Ui}
$$

According to the specification above the estimates of the regression model have been calculated and presented in Table 5. The table presents the regression coefficient of each of the independent variable, its t-statistics, standard error and p-value.

Table 5. Estimates of regression coefficients between stock price and independent variables

\begin{tabular}{lllll}
\hline Variable & Coefficient & Std. Error & t-Statistic & Prob. \\
\hline DLOG(INFR) & -0.034732 & 0.023705 & -1.465171 & 0.1511 \\
\hline DLOG(FEXR) & 0.007896 & 0.138694 & 0.056933 & 0.9549 \\
\hline DLOG(COIL) & 0.056212 & 0.046486 & 1.209229 & 0.2340 \\
\hline DLOG(CCPT) & 0.281059 & 0.160843 & 1.747411 & $0.0486^{* *}$ \\
\hline DLOG(MCAP) & 0.917573 & 0.104933 & 8.744406 & $0.0000^{* * *}$ \\
\hline DLOG(MS) & 0.338907 & 0.136923 & 2.475157 & $0.0179^{* *}$ \\
\hline DLOG(MTV) & -0.19117 & 0.09554 & -2.000933 & $0.0526^{*}$ \\
\hline MTSY & 0.001079 & 0.030482 & 0.035389 & 0.972 \\
\hline DLOG(KSI(-1)) & -0.066484 & 0.043546 & -1.526756 & 0.1351 \\
\hline C & -0.002295 & 0.02085 & -0.110091 & 0.9129 \\
\hline R-squared & 0.830278 & & & \\
\hline Adjusted R-squared & 0.790081 & & & \\
\hline S.E. of regression & 0.099614 & & & \\
\hline Sum squared resid & 0.377074 & & & \\
\hline Log likelihood & 48.20731 & & & \\
\hline F-statistic & 20.65506 & & & \\
\hline Prob(F-statistic)+ 0.000000 & & & \\
\hline
\end{tabular}

Note: $* * *$ and $* * *$ indicates statistical significance at $1 \%, 5 \%$ and $10 \%$ respectively.

As Table 5 shows the DLOG (MKTCAP) has a high positive regression coefficients and its t-statistics and p-value indicate that the coefficient of market capitalization is statistically significant at 1 percent level. DLOG (CCPT) and DLOG (MS) provide high positive regression coefficients and their t-statistics and p-values indicate that the coefficients are statistically significant at 5 percent level. DLOG (MTV) provides a negative regression coefficient and its t-statistics and p-value indicate that the coefficient is statistically significant at 10 percent level. DLOG (FEXR) and DLOG (COIL) provide positive regression coefficients and their t-statistics and p-values indicate that the coefficients are statistically insignificant at 5 percent level. DLOG (INFR) provides a negative regression coefficient and dummy (MTSY) provides a positive regression coefficient and its t-statistics and p-value indicate that the coefficient is statistically insignificant at 5 percent level. The F-statistic p-value also indicates that the 
independent variables are jointly significant at $1 \%$. The model produces a high R-squared value of 0.830278 and an adjusted R-squared value of 0.790081 , which asserts the explanatory power of the regression model in explaining the variations in the KSE all- share price index, that is, DLOG (KSI).

The regression model has been examined for the presence of serial correlation in the residuals using the Breusch-Godfrey Serial Correlation LM Test. The results displayed in Table (6) indicate that the null hypothesis of no serial correlation in the regression residuals cannot be rejected at 5 percent significance level. Thus the regression model is free from serial correlation in the residuals.

Table 6. Breusch-Godfrey serial correlation LM test

\begin{tabular}{llll}
\hline F-statistic & 0.226470 & Prob. F(2,36) & 0.7985 \\
\hline Obs*R-squared & 0.596416 & Prob. Chi-Square(2) & 0.7421 \\
\hline
\end{tabular}

The Histogram Normality Test depicted in Figure 1 shows that the p-value of Jarque-Bera is 0.2315 which implies that the null hypothesis that residuals of the regression models are normally distributed cannot be rejected at 5 percent significance level.

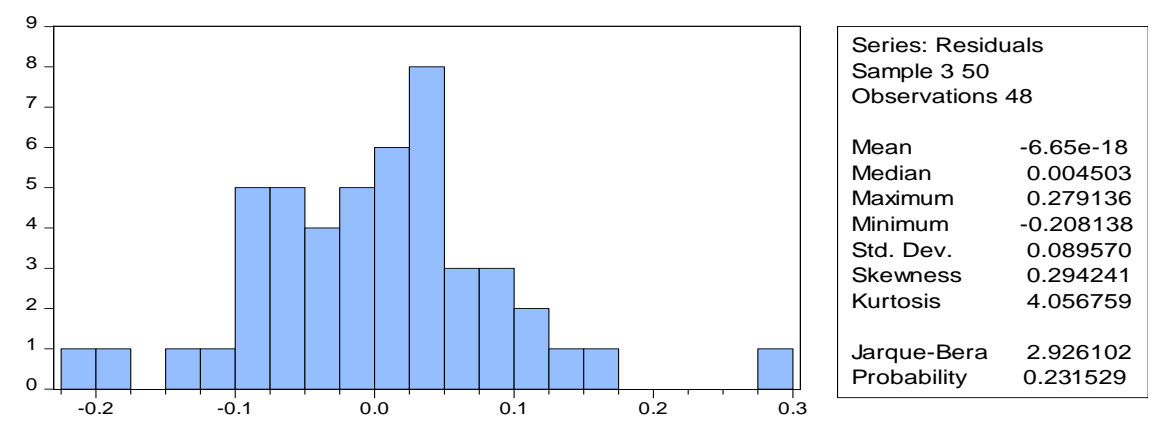

Figure 1. Histogram normality test (Jarque-Bera)

The viability of the regression model is examined for the existence of multicollinearity through estimating and reviewing the Tolerance Value, Variance Inflation Factor (VIF) and Condition Index. If the tolerance value is greater than 0.20 , the variance inflation factor is less than 4.0 and the condition index is less than 3 , then it can be said that the independent variables are not strongly associated with each other which leads to the conclusion that regression model is free from multicollinearity problem. Table 7 reveals no multicollinearity in the model

Table 7. Test of multicollinearity in the regression model between stock price and independent variables

\begin{tabular}{llll}
\hline Variables & Tolerance Value & VIF & Condition Index \\
\hline DLOG(MCAP) & 0.584 & 1.766 & 2.852 \\
\hline DLOG(MTV) & 0.885 & 1.140 & 2.572 \\
\hline MTSY & 0.947 & 1.092 & 1.545 \\
\hline DLOG(FEXR) & 0.582 & 1.770 & 2.078 \\
\hline DLOG(MS) & 0.421 & 1.987 & 2.896 \\
\hline DLOG(INFR) & 0.958 & 1.061 & 1.559 \\
\hline DLOG(COIL) & 0.945 & 1.097 & 1.541 \\
\hline DLOG(CCPT) & 0.841 & 1.194 & 2.287 \\
\hline DLOG(KSI(-1)) & 0.952 & 1.079 & 1.555 \\
\hline
\end{tabular}

The results of the Wald Test, White's General Heteroskedasticity Test and Ramsey's RESET test are portrayed in Tables 8,9 and 10 respectively. 
Table 8. Wald test

\begin{tabular}{llll}
\hline Test Statistic & Value & Df & Probability \\
\hline F-statistic & 20.65506 & $(9,38)$ & 0.0000 \\
\hline Chi-square & 185.8955 & 9 & 0.0000 \\
\hline
\end{tabular}

It is apparent from Table 8 that the null hypothesis of joint regression coefficients is not different from zero cannot be accepted at 5 percent significance level, which confirms the joint statistical significance of all regression coefficients in the regression model.

Table 9. White's general heteroskedasticity test

\begin{tabular}{llll}
\hline F-statistic & 2.549733 & Prob. F(43,5) & 0.1486 \\
\hline Obs*R-squared & 46.86285 & Prob. Chi-Square(43) & 0.317 \\
\hline Scaled explained SS & 38.70171 & Prob. Chi-Square(43) & 0.6581 \\
\hline
\end{tabular}

The results of the homoskedasticity test in Table 9 show that the p-value of the F-statistics and Obs*R-squared statistics are 0.1486 and 0.3170 respectively which implies that null hypothesis of homoskedastic residuals cannot be rejected at 5 percent significant level, thus the residuals are homoscedastic.

Table 10. Ramsey RESET test for regression model between stock price and independent variables

\begin{tabular}{llll}
\hline & Value & df & Probability \\
\hline t-statistic & 1.993125 & 37 & 0.0537 \\
\hline F-statistic & 3.972548 & $(1,37)$ & 0.0537 \\
\hline Likelihood ratio & 4.89525 & 1 & 0.0269 \\
\hline
\end{tabular}

As it appears from Table 10 the value of F-statistic is 3.9725 with a p-value of 0.0537 , which accepts the null hypothesis of having no specification error in the multivariate regression model.

To estimate the long run equilibrium relationship between KSE all-share price index (KSI) and the selected variables, Soren Johansen's $(1900,1995)$ methodology of testing cointegration has been used. The following steps have been followed to conduct Johansens's Cointegration test:

(1) The Cointegration test starts with identifying the order of integration for each specific endogenous variable by applying the Augmented Dickey-Fuller (ADF) Test and Phillips-Parron (P-P) Test. Any variable which does not have the same order of integration, is not incorporated in the test.

(2) An optimal lag length is found using the Akaike info criterion (AIC).

(3) A VAR model has been developed to determine the rank of $\pi$, that is, the value of ' $r$ ' which implies the number of cointegrated vectors.

(4) The trace statistics has been applied to identify the number of cointegrating vectors in the system, if the endogenous variables are found to have cointegrating relationship, then normalized cointegrating equations need to be set to identify their long run equilibrium relationship in detail.

The research incorporates all the endogenous variables for the selection of appropriate lag length. Different methods for selection of optimal lag length have been used including LR sequential modified test statistic (LR), Final Prediction Error (FPE), Akaike Information Criterion (AIC), Schwarz Information Criterion (SC) and Hannan-Quinn Information Criterion (HQ). The optimal lag length has been identified based on AIC, which is a lag length of 3 . This selection is also supported by the FPE method. So the optimal lag length of 4 has been chosen for the application of Johansen's Cointegration test. This information is summarized in Table 11. 
Table 11. VAR lag order selection criteria

\begin{tabular}{lllllll}
\hline Lag & LogL & LR & FPE & AIC & SC & HQ \\
\hline 0 & 84.39106 & NA & $3.05 \mathrm{e}-13$ & -3.277872 & $-2.920094^{*}$ & -3.143846 \\
\hline 1 & 229.3213 & 226.8473 & $2.02 \mathrm{e}-14$ & -6.057448 & -2.479671 & $-4.717191^{*}$ \\
\hline 2 & 328.3058 & $116.1992^{*}$ & $1.39 \mathrm{e}-14$ & -6.839382 & -0.041606 & -4.292894 \\
\hline 3 & 445.6592 & 91.84179 & $1.04 \mathrm{e}-14^{*}$ & $-8.419965^{*}$ & 1.597810 & -4.667246 \\
\hline
\end{tabular}

Table 12 and Table 13 show the trace statistics and Maximum Eigenvalue cointegration rank tests between Stock Price and Macro Variables.

Table 12. Unrestricted cointegration rank test (trace) between the stock price and macro variables

\begin{tabular}{|c|c|c|c|c|}
\hline \multicolumn{5}{|l|}{ Hypothesized } \\
\hline No. of CE(s) & Eigenvalue & Trace Statistic & 0.05 Critical Value & Prob.** \\
\hline None * & 0.926385 & 409.2143 & 197.3709 & 0.0000 \\
\hline At most $1 *$ & 0.868274 & 289.2045 & 159.5297 & 0.0000 \\
\hline At most $2 *$ & 0.707733 & 195.961 & 25.6154 & 0.0000 \\
\hline At most $3 *$ & 0.643043 & 139.377 & 95.75366 & 0.0000 \\
\hline At most $4 *$ & 0.49589 & 91.99054 & 69.81889 & 0.0003 \\
\hline At most $5 *$ & 0.415044 & 60.48235 & 47.85613 & 0.0021 \\
\hline At most $6 *$ & 0.357693 & 35.81629 & 29.79707 & 0.0090 \\
\hline At most 7 & 0.258409 & 15.45258 & 15.49471 & 0.0507 \\
\hline At most 8 & 0.036293 & 1.700517 & 3.841466 & 0.1922 \\
\hline
\end{tabular}

Trace test indicates 7 cointegrating eqn(s) at the 0.05 level

* denotes rejection of the hypothesis at the 0.05 level

**MacKinnon-Haug-Michelis (1999) p-values

Table 13. Unrestricted cointegration rank test (max-eigen) between stock price and macro variables

\begin{tabular}{|c|c|c|c|c|}
\hline \multicolumn{5}{|l|}{ Hypothesized } \\
\hline Eigen value & Max-Eigen & No. of CE(s) & Statistic 0.05 Critical Value & Prob.** \\
\hline None * & 0.967214 & 57.216 & 61.8055 & 0.0000 \\
\hline At most $1 *$ & 0.904508 & 108.0407 & 55.72819 & 0.0000 \\
\hline At most $2 *$ & 0.865894 & 92.41975 & 49.58633 & 0.0000 \\
\hline At most $3 *$ & 0.648055 & 48.03691 & 43.41977 & 0.0147 \\
\hline At most $4 *$ & 0.585501 & 40.5115 & 37.16359 & 0.0199 \\
\hline At most 5 & 0.424322 & 25.40151 & 30.81507 & 0.1990 \\
\hline At most 6 & 0.363584 & 20.78756 & 24.25202 & 0.1347 \\
\hline At most 7 & 0.260549 & 13.885 & 17.14769 & 0.1404 \\
\hline At most 8 & 0.05530 & 2.616866 & 3.841466 & 0.1057 \\
\hline
\end{tabular}

Max-eigen value test indicates 5 cointegrating eqn(s) at the 0.05 level

* denotes rejection of the hypothesis at the 0.05 level

**MacKinnon-Haug-Michelis (1999) p- values 
As it appears from the tables above, according to MacKinnonHaug-Michelis (1999), the p-values of the trace statistics reveal that there are 7 cointegrating vectors in the system which are statistically significant at 5 percent level. However, the max-eigenvalue statistics indicate that there are 5 cointegrating vectors among the KSI and selected variables at 5 percent significance level. Thus the study selects to use 5 cointegrating vectors in its model.

Table 14 presents the five cointegrating equations with their normalized cointegrating coefficients.

Table 14. Cointegrating equation(s) among stock price and selected variables

\begin{tabular}{llllllllll}
\hline Eq. No & KSI & MCAP & MS & MTV & INFR & EXR & COIL & CCPT & MTSY \\
\hline 1 & 1 & 3.4102 & 0.7161 & 1.0817 & 0.1646 & 1.0637 & 1.0592 & -3.1178 & 0.4240 \\
\hline & & -0.1976 & -0.3438 & -0.1112 & -0.0860 & -0.3141 & -0.1644 & -0.4284 & -0.0457 \\
\hline 2 & 0 & 1 & -1.2446 & -0.5287 & -0.1771 & -0.3199 & 0.3313 & 2.6759 & -0.1997 \\
\hline & & & -0.1769 & -0.0650 & -0.0502 & -0.1859 & -0.0927 & -0.2246 & -0.0267 \\
\hline 3 & 0 & 0 & 1 & 0.2516 & 0.1634 & 0.0717 & -0.3669 & -0.3123 & -0.0251 \\
\hline & & & & -0.0391 & -0.0316 & -0.1172 & -0.0590 & -0.1427 & -0.0169 \\
\hline 4 & 0 & 0 & 0 & 1 & 0.5564 & -0.8627 & -1.6103 & -0.4096 & 0.0231 \\
\hline & & & & & -0.0926 & -0.3469 & -0.1540 & -0.4425 & -0.0527 \\
\hline 5 & 0 & 0 & 0 & 0 & 1 & 2.5940 & -7.7743 & 10.0761 & 0.1645 \\
\hline & & & & & & -2.1598 & -0.9098 & -3.0410 & -0.3643 \\
\hline
\end{tabular}

The first equation indicates that the MCAP has a positive coefficient with KSI meaning that when MCAP increases by 1 percent KSI increases by approximately 3.41 percent. The standard error of this coefficient has been found to be low which implies reliable estimates for the MCAP. Also, the coefficient of MCAP in the 1st cointegrating equation supports the hypothesized relationship between the KSI and MCAP set by this paper; a positive relationship exists between stock price and market capitalization in the long run. The normalized coefficients of MS are 0.7161 and -1.2446 with KSI in equations 1 and 2 respectively. This situation explains that at the presence of MCAP, MS has a positive association with KSI. But when MCAP is absent the same positive relation turned to be negative. The coefficients of MS in the 1st cointegrating equation and MTV in equations 1 and 3 provide positive cointegrating coefficients with KSI, which approves the hypotheses of a long run positive relationship with KSE stock price. INFR, FEXR and MTSY have positive coefficients with KSI in three cointegrating equations and this evidence also supports the hypothesized relationship between KSI and INFR, FEXR and MTSY postulated by the paper. The coefficients of COIL in two cointegrating equations are positive; hence supports the hypothesized relationship between the KSI and COIL. CCPT shows negative coefficients in three equations. As the hypothecated relationship between KSI and CCPT is negative, so this result is in line with the hypothesis established by the research.

Through the application of the Toda-Yamamoto Granger Causality test, the long run causal relationship between the stock price and the set of selected variables has been examined. The test assumes the null hypothesis that there is no causal relation between the stock price and any of the selected variables. If the p-value of the chi-square statistics is less than 0.05 , the null hypothesis of no causal relation between KSI and the selected variables can be rejected. Rejection of the null hypothesis implies that a causal relationship does exist between the dependent and independent variables. The test estimates are presented in Table 15.

Table 15. T-Y Granger causality test between stock price and joint micro-macro variables

\begin{tabular}{|c|c|c|c|c|c|}
\hline \multicolumn{3}{|c|}{ Direction of Causality } & \multirow{2}{*}{$\frac{\mathrm{df}}{4}$} & \multirow{2}{*}{$\frac{\text { Chi-sq. }}{4.574}$} & \multirow{2}{*}{$\frac{\text { Prob. }}{0.334}$} \\
\hline KSI & & MCAP & & & \\
\hline MCAP & $\rightarrow$ & KSI & & 12.232 & 0.016 \\
\hline KSI & & MTV & 4 & 1.889 & 0.756 \\
\hline MTV & & KSI & & 4.101 & 0.393 \\
\hline KSI & & MTSY & 4 & 16.969 & 0.002 \\
\hline MTSY & $\rightarrow$ & KSI & & 2.923 & 0.571 \\
\hline KSI & $\rightarrow$ & CCPT & 4 & 11.875 & 0.018 \\
\hline
\end{tabular}




\begin{tabular}{|c|c|c|c|c|c|}
\hline CCPT & $\rightarrow$ & KSI & & 7.648 & 0.100 \\
\hline KSI & & EXR & 4 & 4.752 & 0.314 \\
\hline EXR & $\rightarrow$ & KSI & & 8.916 & 0.063 \\
\hline KSI & & INFR & 4 & 1.826 & 0.768 \\
\hline INFR & & KSI & & 2.615 & 0.624 \\
\hline KSI & & MS & 4 & 1.120 & 0.891 \\
\hline MS & $\rightarrow$ & KSI & & 8.525 & 0.074 \\
\hline KSI & & COIL & 4 & 4.137 & 0.388 \\
\hline COIL & $\rightarrow$ & KSI & & 9.581 & 0.048 \\
\hline
\end{tabular}

As Table 15 portrays the long run Granger Causal estimates between the stock price and the selected variables reveal that MCAP and COIL granger causes KSI at 5 percent significance, whereas FEXR and MS granger causes KSI at 10 percent significance. In addition a bi-directional causality has been found between KSI and CCPT. On the other hand, KSI granger causes MTSY at 5 percent significance. However, neither unidirectional nor bi-directional causality has been found between KSI and MTV and KSI and INFR.

\section{Discussion}

The results of the statistical analysis evidence that both micro and macro variables are important factors in determining the stock market performance during the tested period. All the macroeconomic variables employed by the study have an association with the KSE performance. The multivariate regression analysis documents a negative but insignificant relationship between the inflation rate and the stock price in the short run. However, the estimates of Johansen's cointegration test reports a long run positive association with the stock price. Within the African stock markets context, this result supports Kirui et al (2014) and Barakat (2016) who report an insignificant relationship between inflation and market performance. As well it is in line with Aigbovo and Izekor (2015) and Amassoma and Bolarinwa (2018) whose studies reveal the existence of a long run relationship between inflation and the stock market index. This can be attributed to the narrowness of the market and the need for longer periods of trading for the effect of inflation to take place. As regarding the cost of capital, the research indicates that it has a positive association with KSI in the short run but it has a negative relationship with the market performance in the long run. Further, market performance also affects and is affected by the cost of capital. This shows the sensitivity of the stock market activities to changes in the cost of financing and the important role played by banks in bringing new investors to the stock market. The results also show a positive influence of the exchange rate on the behavior of KSE. The exchange rate has a long run positive association with the stock price and the causality test provides evidence that KSI responds to changes in the exchange rate. Similar results have been reported regarding the impact of broad money supply on the market performance; a long run positive association between the two variables and a respond of the market performance to the changes in the money supply. Finally, the crude oil price has been found to have a positive association with KSE activities both in the short and long run. As well the Causality test reveals that KSE performance reacts to the changes in crude oil prices.

As regarding the micro factors the research supports the evidence that there is a significant positive relationship between the stock market performance and its market capitalization. Increasing market capitalization reflects the investor's confidence in the stock market, which is expressed in terms of rising demand for the stock, sends a positive message about the performance of the market. To the contrary of the hypothesized relationship between the volume of trading and the Khartoum Stock Exchange performance, the study documents that the impact of trading volume on KSI is negligible in the short run. However in the long run the increase in the volume of trading does enhance the market performance. This is again justifiable on the basis that KSE is a thin market with a low number of buyers and sellers, which necessitates a long period of trading for the effect of trading volume on market performance to materialize. Similarly, the results of the analysis suggest that automation of the trading system has a positive impact on the stock market performance, though the impact is more apparent in the long run. Further, according to causality test KSE performance responds to the changes in the mechanization of the trading activities.

\section{Conclusions}

The paper aims at identifying the short and long run relationships between the Khartoum Stock Exchange all- share price index (KSI) as an indicator of market performance and a number of selected micro and macro-economic factors. 
The micro indicators include market capitalization, market trading system and market trading volume. The inflation rate, cost of capital, foreign exchange rate, broad money supply, and crude oil prices are chosen as proxies for macroeconomic factors. The paper employs many statistical techniques including Multivariate Time Series Regression, Johansen's Cointegration Test, Vector Error Correction Model, and Toda-Yamamoto (T-Y) Granger Causality to test the validity of data and the models developed by the study and undertake the analysis. Based on the results of the analysis, which are generated by Eviews 9 package and statistical computations, the study confirms that the KSE performance is significantly affected by changes in the inflation, exchange rate, money supply and crude oil prices in the long run. In the short run the determinants of the stock market performance are the money supply and cost of capital. As regarding the micro factors, the research provides evidence that stock market performance is positively affected by its market capitalization and automation of its trading system. The volume of trading, however, has no impact on market performance. The causality test documents unidirectional relationship that runs from FEXR, MS, COIL, MCAP, and MTSY to KSI. The only bi-directional causality relation exists between KSI and CCPT.

Several practical implications can be derived from these results. Theoretically, the research asserts that the macroeconomic factors in addition to micro variables are strongly associated with the stock market performance regardless of the degree of development of the stock market. Whether in developed, emerging, or developing countries stock prices are affected by measures of economic activity such as inflation, interest rate, exchange rate, money supply, GDP, cost of capital, and oil prices. Thus government policies regarding stock market enhancement should take into consideration this association. Since the stock prices interact with the key macroeconomic variables, sound economic and financial policies can yield remarkable improvements in the stock market achievements. The short run impact of the money supply and cost of capital on the KSI necessitates that monetary policies regarding the cost of financing and the total value of money available in the economy should consider the spillovers of such policies on the stock market activities. Further, the bi-directional relationship between the KSI and the cost of capital sends a message to banks' management to give attention to the market performance when setting the cost of their financing modes. Those who are entrusted with the management of the stock market should adopt and implement policies that boost the institutional setting of the market, such as improved trading, sound accounting and information reporting systems, strong and readily enforceable legal procedures, and effective clearing and settlement arrangements. Such measures have proven to have a positive impact on stock market performance. The results of the study could be beneficial to investors, both individual and institutional, in that when making investment decisions adequate consideration should be given to the general economic climate in addition to the market specific conditions.

\section{References}

Abass, N. (2010). Stock Market in Sudan: Thirteen Years of Experience. Khartoum University Journal of Management Studies, 3(1), 118-161.

Abdullah, D., \& Hayworth S. (1993). Macroeconometrics of stock price fluctuations. Quarterly Journal of Business and Economics, 32(1), 49-63.

Abugri, B. A. (2008). Empirical relationship between macroeconomic volatility and stock returns: Evidence from Latin American markets. International Review of Financial Analysis, 17(2), 396-410. http://doi.org/10.1016/j.irfa.2006.09.002

Adam, A., \& Tweneboah, G. (2008). Macroeconomic Factors and Stock Market Movement: Evidence from Ghana. MPRA Paper, 11256. https://doi.org/10.2139/ssrn.1289842

Aigbovo, O., \& Izekor, A. (2015). Impact of macroeconomic variables on stock market index in Nigeria. African Journal of Management Sciences, 1(1), 18-40.

Amassoma, D., \& Bolarinwa, I. (2018). A Time series analysis of the nexus between macroeconomic fundamentals and stock prices in Nigeria. Studies in Business and Economics, 13(2), 69-91. https://doi.org/10.2478/sbe-2018-0021

Bagchi, B. (2017). Volatility spillovers between crude oil price and stock markets: evidence from BRIC countries. International Journal of Emerging Markets, 12(2), 352-365. https://doi.org/10.1108/IJoEM-04-2015-0077

Balvers, R. J., Cosimano, T. F., \& McDonald, B. (1990). Predicting stock returns in an efficient market. Journal of Finance, XLV, 1109-1135. https://doi.org/10.1111/j.1540-6261.1990.tb02429.x

Barakat, M., Elgazzar, S., \& Hanafy, K. (2015). Impact of macroeconomic variables on stock markets: Evidence from emerging markets. International Journal of Economics and Finance, 8(1), 195. https://doi.org/10.5539/ijef.v8n1p195 
Barro, R. J. (1990). The stock market and investment. Review of Financial Studies, 3, 115-131. https://doi.org/10.1093/rfs/3.1.115

Bernanke, B., \& Blinder, A. (1992). The federal fund rate and the channels of monetary transmission. American Economic Review, 82, 901-921.

Büyüksalvarci, A., \& Abdioglu, H. (2010). The causal relationship between stock prices and macroeconomic variables: A case study for Turkey. International Journal of Economic Perspectives, 4(4), 601-610.

Caner, S., \& Onder, Z. (2005). Sources of volatility in stock returns in emerging markets. Applied Economics, 37(8), 929-941. https://doi.org/10.1080/00036840500061046

Chen, N. (1991). Financial investment opportunities and the macroeconomy. The Journal of Finance, 46(2), 529-554. https://doi.org/10.1086/296344

Chen, N., Roll, R., \& Ross, S. (1986). Economic forces and the stock market. Journal of Business, 383-403.

Cheng, A. (1995). The U.K. stock market and economic factors: a new approach. Journal of Business Finance and Accounting, 22(1), 129-142. https://doi.org/10.1111/j.1468-5957.1995.tb00675.x

Czapkiewicz, A., \& Stachowicz, M. (2016). The long-run relationship between the stock market and main macroeconomic variables in Poland. Managerial Economics, $17(1), \quad 7$. https://doi.org/10.7494/manage.2016.17.1.7

Dickey, D., \& Fuller, W. (1981). Likelihood Ratio Statistics for Autoregressive Time Series with a Unit Root. Econometrica, 4, 1057-1072. https://doi.org/10.2307/1912517

Elbeely, et al, (2013). Correlation and causality between Khartoum Stock Exchange index fluctuations and macroeconomic variables: Empirical study on Sudan Economy (2003-2012). SUST Journal, 15(2). Retrieved from http//journals.sustech.edu/

Enders, W. (2004). Advanced Econometric Time Series (2nd ed., Chapter 6). John Willey \& Sons, Inc.

Engle, F., \& Granger, C. W. J. (1987). Co-integration and Error Correction: Representation, Estimation, and Testing. Econometrica, 55, 251-276. https://doi.org/10.2307/1913236

Gani, A., \& Ngassam, C. (2008). Effect of institutional factors on stock market development in Asia. American Journal of Finance and Accounting, 1, 103-120. https://doi.org/10.1504/AJFA.2008.019947

Gunasekarage, A., \& Pisedtatalasai, A. (2004). Macroeconomic Influence on the Stock Market: Evidence from an Emerging Market in South Asia. Journal of Emerging Market Finance, 3(3), 285-304. https://doi.org/10.1177/097265270400300304

Haruna, I., Yazidu, U., \& Paul, B. (2013). Macroeconomic variables and stock market returns in Ghana: Any causal link?. Asian Economic and Financial Review, 3(8), 1044-1062.

Hosseini, S., Ahmad, Z., \& Lai, Y. (2011). The role of macroeconomic variables on Stock market index in China and India. International Journal of Economics and Finance, 3(6), 233-243. https://doi.org/10.5539/ijef.v3n6p233

Jareño, F., \& Negrut, L. (2016). US Stock Market and Macroeconomic Factors. Journal of Applied Business Research, 32, 325-340. https://doi.org/10.19030/jabr.v32i1.9541

Khalid, W., \& Khan, S. (2017). Effects of Macroeconomic Variables on the Stock Market Volatility: The Pakistan Experience. International Journal of Econometrics and Financial Management, 5(2), 42-59.

Khandelwal, R. (2018). An Econometric analysis of linkages between macroeconomic variables and stock markets: Evidence from Asian emerging markets. International Journal of Financial Management, 8(1), 27-35.

Khanyisa, N., Kapingura, F., \& Palesa, M. (2016). The interaction between the stock market and macroeconomic policy variables in South Africa. Journal of Economics, 7(1), 1-10. https://doi.org/10.1080/09765239.2016.11907815

Kirui, E., Wawire, N., \& Onono, P. (2014). Macroeconomic Variables, Volatility and Stock Market Returns: A Case of Nairobi Securities Exchange, Kenya. International Journal of Economics and Finance, 6(8). https://doi.org/10.5539/ijef.v6n8p214

Kyereboah-Coleman, A., \& Agyire-Tettey F. (2008). Impact of macroeconomic indicators on stock market performance: The case of the Ghana Stock Exchange. Journal of Risk Finance, 9(4), 365-378. https://doi.org/10.1108/15265940810895025 
Lee, B. (1992). Casual relations among stock returns, interest rates, real activity, and inflation. The Journal of Finance, XLVII, 1591-1603. https://doi.org/10.1111/j.1540-6261.1992.tb04673.x

Mayur, M. (2017). Asian economic forces and stock price in an emerging market: The case of India. Asian Economic and Financial Review, 7(8), 760-769. https://doi.org/10.1111/j.1540-6261.1992.tb04673.x

Megaravalli, A., \& Sampagnaro, G. (2018). Macroeconomic indicators and their impact on stock markets in ASIAN 3: A pooled mean group approach. Cogent Economics \& Finance, 6(1), 1432450. https://doi.org/10.1080/23322039.2018.1432450

Mensia, W., Hammoudehc, S., Yoond, S., \& Balcilar, M. (2017). Impact of macroeconomic factors and country risk ratings on GCC stock markets: evidence from a dynamic panel threshold model with regime switching. Applied Economics, 49(13), 1255-1272. https://doi.org/10.1080/00036846.2016.1217305

Mukherjee, T., \& Naka, A. (1995). Dynamic relations between macroeconomic variables and the Japanese stock market: an application of a vector error correction model. Journal of Financial Research, 18(2), 223-237. https://doi.org/10.1111/j.1475-6803.1995.tb00563.x

Nasseh, A., \& Strauss, J. (2000). Stock prices and domestic and international macroeconomic activity: a cointegration approach. The Quarterly Review of Economics and Finance, 40(2), 229-245. https://doi.org/10.1016/S1062-9769(99)00054-X

Nath Sahu, T., Bandopadhyay, K., \& Mondal, D. (2014). An empirical study on the dynamic relationship between oil prices and Indian stock market. Managerial Finance, 40(2), 200-215. https://doi.org/10.1108/MF-06-2013-0131

Olweny, T. (2015). The Impact of Information Technology on Stock Market Development in Kenya. Conference: The 10th JKUA Scientific, Technological and Industrialization Conference and Exhibitions, JKUAT, Nairobi, Kenya.

Pal, K., \& Mittal, R. (2011). Impact of macroeconomic indicators on Indian capital markets. The Journal of Risk Finance, 12(2), 84-97. https://doi.org/10.1108/15265941111112811

Pilinkus, D. (2010). Macroeconomic indicators and their impact on stock market performance in the short and Long run: the case of the Baltic States. Technological and Economic Development of Economy, 16(2), 291-304.

Schwert, W. (1990). Stock returns and real activity: a century of evidence. Journal of Finance, XLV, 1237-1257. https://doi.org/10.1111/j.1540-6261.1990.tb02434.x

Toda, H., \& Yamamoto, T. (1995). Statistical Inferences in Vector Autoregressions with Possibly Integrated Processes. Journal of Econometrics, 66, 225-250. https://doi.org/10.1016/0304-4076(94)01616-8

Tripathi, V., \& Seth, R. (2014). Stock Market Performance and Macroeconomic Factors: The Study of Indian Equity Market. Global Business Review, 15(2), 291-316. https://doi.org/10.1177/0972150914523599

Utomo, S., Wulandari, D., Narmaditya, B., Handayati, P., \& Ishak, S. (2019). Macroeconomic factors and LQ45 stock price index: evidence from Indonesia. Investment Management and Financial Innovations, 16, 251-259. https://doi.org/10.21511/imfi.16(3).2019.23

Wongbangpo, P., \& Sharma, S. (2002). Stock market and macroeconomic fundamental dynamic lnteractions: ASEAN-5 countries. Journal of Asian Economics, 13, 27-51. https://doi.org/10.1016/S1049-0078(01)00111-7

Worlui, C., \& Omodero, C. (2017). A Comparative Analysis of Macroeconomic Variables and Stock Market Performances in Africa (2000-2015). International Journal of Academic Research in Accounting, Finance and Management Sciences, 7(4), 95-102. https://doi.org/10.6007/IJARAFMS/v7-i4/3436

Yartey, C. (2008). The Determinants of Stock Market Development in Emerging Economies: Is South Africa Different?. IMF Working Paper WP/08/32. https://doi.org/10.5089/9781451868944.001 